\title{
The State Concept: The Political Thinking of Mohammad Natsir
}

\author{
RIS'AN RUSLI ${ }^{1}$
}

\begin{abstract}
State is an institution that accommodates the interests of individuals within the scope of community life. The concept of the state has a strategic role in determining various policies on all aspects including politics, society, economy, and education. In its journey, the form and concept of the state became a matter of debate and difference of views. One of the Muslim intellectuals providing views on the concept of the state is Mohammad Natsir. Natsir holds that the head of the state should be good person morally, democratically, constitutionally and has the support from the people. He offers the conception of a moral state and a clean government. He also discusses about the nature of the head of the state (imam), the need for the head of the state, the character of the head of the state, the appointment and determination of the head of the state, and also about his position on Indonesian's Pancasila.
\end{abstract}

Keywords: Indonesian politics, Mohammad Natsir, leadership in Islam, Pancasila, state

Talking about the concept of the state as part of the political aspect is an interesting study to discuss. This is because the effort to determine the concept and shape of the state has a backlash against the color of a country's political policy. The state is the historical embodiment of a social collectivity in fulfilling the demands of human dignity in which a state is founded (Balandier 1986: 161). Its existence is a system of execution of rules which has been agreed upon by the human community in a particular territory. The state is an institution that seeks to accommodate individual interests in a social life order into a collective interest. Its form, at least, is a series of three main pillars of the general terms of a country. The main pillars are territorial, community, and governance structures (Sukarja 1995: 88). These criteria are not specific in pointing to the concept and form of the state. The specifications are just emerging from the interaction and consensus of the communities in which the country stands that is influenced by various other internal and external factors. Specification of the collective desire of that, distinguishes between the form and concept of the state. The specifications of the form and concept of the country are liberal, autocracy and so forth.

Among Muslims, the issue of state forms and concepts is a study that often invites debate and dissent. This arises because neither in the Quran nor the Hadith mentions clearly the form and concept of the state that must be developed by its people. These two grounds only provide the basic principles of an ideal state, as Islam desires. Therefore, the Muslim intellectuals try to interpret these basic principles in a formula of state concept. Among these intellectuals is Mohammad Natsir (hereinafter referred to as Natsir). As a famous democrat, Natsir was also a prominent political expert in the Modern age. One of his intensive thoughts on politics is to discuss the concept of the state. For that, this paper tries to explore how the

1 Ris'an Rusli, Ph.D., professor at Faculty of Psychology, Universitas Islam Negeri Raden Fatah Palembang, Jalan Prof. K.H. Zainal Abidin Fikri KM. 3,5 Palembang Sumatera Selatan, 30126 Indonesia, email: risanrusli_uin@radenfatah.ac.id. 
concept of state according to Natsir political thought and the importance of the state for humans, as well as the ideal criteria of a head of state.

\section{Life of Mohammad Natsir}

Mohammad Natsir titled Datuk Sinaro Panjang (Puar 1978: 4), was born on Jembatan Berukir, Alahan Panjang, Solok district of West Sumatra on Friday 17 July 1908 to coincide with the date of 17 Jumadil Akhir $1326 \mathrm{H}$ from a woman named Khadijah. His father is Mohammad Idris Sutan Saripado, a lowly clerk who had been a clerk at the control office in Maninjau. In 1918 he was transferred from Alahan Panjang to Ujung Pandang South Sulawesi as a warden (guard of the prisoners). He has three siblings namely Yukinan, Rubi'ah and Yohanusun (Salam 1990: 131). He attended elementary school at the Dutch school, which was a private school of HIS (Hollandsch-Inlandsche School) Adabiah in Padang in 1961 and studied religion diligently to some prominent scholars (Junus 1985: 63 and 153). In the same year he was transferred to HIS Government in Solok by his father after several months of schooling in Padang. In the afternoon, he studied at Madrasah Diniyah and studied the Qur'an in the evening (Noer 1990: 100). In 1920, he moved back to Padang over his Brother Rubi'ah's invitation. On that same year he entered the State HIS (Netherlands) education and graduated in 1923 (Puar 1978: 5-6).

Furthermore, in 1923, he entered the school MULO (Meer Uitgebreid Lager Onderwijs) in Padang and actively follows the activities of an extra-curricular on his passion. He was a member of the Nationale Islamietische Padvinderij scout, a current Scout, run by the Jong Islamieten Bond (JIB) Padang association headed by Sanusi Pane. In the same year, he continued his formal education to Algemeene Middelbare School (AMS) Afdeling A in Bandung. In this city, the long history of his struggle is begun. He met the radical figure, Ahmad Hassan (Natsir 1989: 30-32), the founder of PERSIS, who admitted heavily influenced his mind. With this last character, he studied the religion of Islam deeply and engaged in the movement of politics, Islamic missionary and education.

A fortune for Natsir that at the age of 20, he had interacted with national figures, such as Mohammad Hatta, Prawoto Mangunsasmito, Yusuf Wibisono, Tjokroaminoto and Mohammad Roem (Mahendra 1994: 65). In JIB, he discussed with friends of his age. His outstanding intellectual abilities and his quiet discussions and personality led him to occupy the chair of JIB Bandung from 1928 to 1932 and thus his political abilities improved. Thus, his daily activities at his early schooling at AMS (Algemeene Middelbare School) had influenced his soul to earn the title of Meester in de Rechten (Mr) (Puar 1978: 20) who became his ideals and the ideals of both of his parents. But in the middle of the final study in the school, some attention and interest has been inhaled by the problems of society and the development of Islam and the movement of Muslims, so arise the desire to go directly to serve the community and devoted to God in helping and lifting the degree of Muslims who are oppressed by the Dutch colonialism (Puar 1978: 1819).

After studying in AMS, he did not continue his education to a higher level (university), but he taught Islam in the school MULO Javastraat Bandung and school teacher in Gunung Sahari, Lembang. This fact was his soul's call to teach a religion which at that time he felt was inadequate and he argued that education is the most important field of any other field (Puar 1978: 18-19). In 1938, he began his political activities by registering as a member of the Indonesian Islamic Party (PII) branch of Bandung. Two years later, he was the chairman of the Bandung branch of PII (1940). He was honored to be a member of the Bandung Regency Council (Regentschapraad) from 1940 to 1942 and worked in the government as Head of the Bureau of Education of Bandung until 1945 and concurrently secretary of Islamic High School (STI) in Jakarta (Mahendra 1994: 65).

In the early days of Indonesian independence, he appeared to be one of the politicians and leaders of the country. In his political career, he became a member of the Central 
Indonesian National Committee (KNIP), the Minister of Information (1946-1948), member of the Provisional House of Representatives (DPRS) and the first Prime Minister of the Republic of Indonesia (1950). The inauguration of Natsir as prime minister was a logical and natural consequence of his position as chairman of the Masyumi party, the largest political party of the day marked by the most seats in the House of Representatives. His appearance to the top of government is inseparable from his strategic move in expressing a motion at the parliamentary session of the Republic of Indonesia (RIS) on April 3, 1950, better known as Integral Motion of Natsir. That motion allowed the divided Republic of Indonesia (RI) - as a result of the Round Table Conference (KMB) - into 17 states, again becoming a unitary state of the Republic of Indonesia. His big name also spread abroad because of his international activities, especially in the Middle East region. In 1956 he along with Sheikh Maulana Abul A'la Maududi (Lahore) and Abul Hasan an-Naduri (Lucknow) presided over the Mu'tamar 'Alam Islamy trial in Damascus. $\mathrm{He}$ is also become the Vice President of Pakistan-based World Congress of Islam and Mu'tamar 'Alam Islamiy in Saudi Arabia. In the same year, he performed the pilgrimage to the Holy Land of Mecca (Salam, 1990: 132).

Internationally, he is known for his unequivocal support for the independence movement of Muslim nations in Asia and Africa, and his efforts to raise cooperation between newly independent Muslim countries. It seems not excessive if Inamullah Khan called Natsir as a one of the great figures of the Islamic world on that century. As an elder of political leaders, he is often asked for advice and views by PLO (Palestine Liberation Organisation) figures, Mujahideen of Afghanistan, Moro, Bosnia as well as non-Muslim world political figures such as from Japan and Thailand (Mahendra 1994: 65).

In honor of his devotion to the Islamic world, he received an international award in the form of a Star Award from Tunisia and from the Faisal Foundation of Saudi Arabia (1980). In the academic world, he received a Doctorate Honoris Causa (HC) from the Islamic University of Lebanon (1967) in literature, University of Kebangsaan Malaysia and University Saint Teknologi Malaysia (1991) in the field of Islamic thought (Salam 1990: 132). Besides receiving numerous awards, he also left the knowledge for Muslims and the Indonesian nation, he has written 52 of book titles on various occasions since 1930 (Puar 1978: 406-409). Apparently, Sukarno's statement in 1936 about Natsir was a high-quality muballigh is definitely right, and that is an answer to the demands of his time, because he was an intellectual Muslim, and a thinker. He donate much of his thoughts on the various religious problems, social and state issues to his homeland and Indonesian nation. Regarding to his works, his thoughts remains in history as a valuable contribution to the Indonesian nation seeking to identify and build its future. History records that Indonesia in the twentieth century, possessed a figure of Muslim intellect and thinker who are international caliber.

He passed away on February 6, 1993 to coincide with 14th Sya'ban 1413 H at Cipto Mangunkusomo Hospital Jakarta at the age of 85 after suffering from bronchitis complications, respiratory problems (asthma) and urinary (prostate) blockage (Hakiem 1993: 144).

\section{Natsir's View of the State}

Talking about the state, political scholars often use it in terms of khilafah and imamah. Its a warmly debated kalam themes among mutakallimin, such as among Shi'a, Mu'tazila and alAsh'ariah. In a glance it appears that the issue of khilafah and imamah is more dominate the political problem at the beginning of the emergence of Islam. But in it turn, it brings up the theological tendencies and gives rise to various streams. This is because since the emergence of differences in the early days of Islam relating to religious interests, various schools have developed different Islamic versions and formed different religious associations within Islamic societies in general (Syamsuddin 2001: 93). In this context, according to M. Din Syamsuddin (2001: 93) citing the views of Hamid Enayat, the khilafah which is one of Islamic political 
thought becomes subordinate and part of theology and Islamic jurisprudence, which in reality can be seen that political issues are not discussed separately from the various disciplines and all intertwined in the irrefutable sphere of shari'a.

The following descriptions illustrate Natsir's point of view in relation to the five subjects in discussing the State. First, the essence of the head of state (imam). Second, the need for the head of state. Third, the character of the head of state. Fourth, the appointment and determination of the head of state (imam). Fifth, Islam and Pancasila.

\section{The Essence of the Head of State (Imam)}

In Natsir's understanding, God's sovereignty as the "gravitational center" of Islam, is the real sovereignty of Allah Almighty and Omnipotent. It divides sovereignty into two kinds, namely de jure sovereignty, which belongs to God and de facto sovereignty which is inherent and distinctly present in all the motion and workings of the universe. It includes the political sovereignty that belongs to God (Natsir 1957: 140). Thus the power or authority that exists in man is a sacred mandate that is naturally within the limits of God's will. For him, the question of name for the leader of the country is not a big problem. He does not insist on naming it as Khalifah, Imam, Head of State, or President. He states that "the title of Khalifah is not an absolute requirement in government (Islam), not conditio sine qua non. But the head of state who get the power, is required to act wisely and observe the Islamic law in proper way in the state structure, both in rule and in practice "(Natsir 1957: 443).

Natsir argues that the power in the hands of a country's sovereign is a God's gift. It is a mandate for the person to be executed in accordance with the norms outlined by Almighty God, the Just. Power is not merely to rule, but to uphold law and justice, to grant the right to anyone who is entitled to it, even if the right is in a weak position. It will be safe to reconcile a society, in its view, as long as there are leaders and rulers who realize that the authority in their hands is the divine mandate and the mandate of the people, which must be used to uphold justice so that the weak will not be oppressed and the strong do not oppress (Natsir 1967: 15-17).

According to Natsir, Allah SWT reminds the rulers with their destruction of self-will and will without regard to the norms of justice and truth (Natsir 1975: 39-40). See the Qur'an letter of Ibrahim verse 42. State affairs in Islam is one part (intergreerend deel) of Islam itself. Islam does not recognize the "Head of Religion" as the Pope or Cardinal in Christianity. Islam only knows Muhammad Rasullah s.a.w. as religious and state leaders. He has passed away and no subtitutes for him forever, and has abandoned a system called Islam, which must be practiced by the Muslims and continues to be maintained and to be run by a leader, whether the title is King, Khalifah, President or any other title who holding Power within an Islamic state. The companions of the Prophet who once held state authority after the Prophet like Abu Bakr, Umar Ibn al-Khattab, Uthman Ibn 'Affan and Ali Ibn Abi Talib did not concurrently become 'Head of Religion'. They were merely leaders who made his rule run on the rules that had been abandoned by Muhammad's last Apostle (Natsir 1957: 458-459).

He likens the state controller (leader) to a ship. He said:"We are all in a "state ship". Let us work together in their respective chambers, by maintaining harmony between all the children of the state ship and its passengers. If we are grateful for the favors of the state by obeying the law of harmony in it, then we will get additional favors more. But when we deny the rule of law, we will drown all in misery. "(Natsir 1957: 313). The leader, he says, must be born from the bottom. He was born as a leader because society and his group thought he was worthy and deserving to be a leader. Not because "he's a candidate for leader". He should look around to make various "approaches" to the various parties so that he could appointed as a leader (Mahendra 1994: 4).

From this view, it appears that the character of leadership and power held by a person is a mandate from the crowd. As a mandate, it is surely an obligation for the leader to fulfill it. If 
the leader is seen as a mandate, the next implication is: he is obliged to uphold the ethics of his leadership and is universal (Mahendra 1994: 4).

\section{Needs for the Head of State}

In the matter of need to the head of state, Natsir stated that the need for the leader is a natural law in the field of human life. It is a necessity, for the salvation and development of all people in a society, because man is a social being who can not live alone. A person can only survive and progress in one community bond. In the chaos and dislike of the joys, he can not develop his talents and potentials. The continuation of his life requires order as a sine quo non. There is no order if there is no leadership. From there radiates order, and to that place repatriates to solve it (Natsir n.d). In addition to the ratio argument, he also points out the words of the Prophet: "that when three people walk together, one of the three functions as a leader", in order to survive the journey.

In his view, it turns out that talk of the needs of the head of state or imam in a country is important. It seems that he sees it as a practical necessity in its operation alone. This view is also apparent in the analogy of the head of state with the imam in the prayer that he proposes. He explained the imam's link in prayer that his role is only as a priest, a leader of prayer. The existence of a priest as an official position, specifically to perform the prayer, is not in Islam. The priest is merely a position based on the practical necessities of worship, not an official title (Natsir 1955: 6). His view is based on his understanding of the definition (religion) of Islam. For him, Islam is an ideology. Islam is not merely a religion in terms of the relationship between man and his God. Islam contains two elements, namely the element of human relations with God and the element of human relationships with fellow beings. The elements of worship and mu'amalah (Natsir N.d: 129). In the element of mu'amalah includes individual life, and social community; "The latter is no more-no less, is called the state affairs" (Natsir 1957: 436).

In his view, the Quran and the Sunnah of the Prophet did not have the hands and feet to guard the rules which were in it which was run by man. As with the scriptures and other books of the law, the Qur'an can not do anything by itself, and its ordinances will not run by itself, merely being put on a cupboard or even upright the head of every people (Natsir 1957: 437). It functioned when enabled by adherents. In this case, he exemplifies that Islam obliges Muslims to pay zakat accordingly. How this social law can apply correctly, if there is no government that oversees the obligation (Natsir 1957: 441). Thus, in his opinion, to keep the rules and standards runs well and to proceed as they should, there must be a force in the social life, that is, the power within the State (Natsir 1957: 437). This is where the importance of state institutions as a tool to apply the laws that already exists. In the absence of a state, it is difficult to obedience the laws.

From the views expressed above, shows that for Natsir the need for state power is the elaboration of the Islamic teachings that are summed up in the element of mu'amalah. He said that in the face of state problems, such as the Constitution of the State, then by itself he will deal with the Islamic teachings which are summed up in the second element, namely the element of mu'amalah (Harjono 1996: 129).

For Natsir, the need for the state is not the goal of Islam, but as a tool. State affairs are essentially an inseparable part, an integration or integrieren of Islam. The State serves as a means to achieve the goal of "the perfection of the coming into effect of the Divine Law, both with respect to the life of man as an individual, and as a member of society" (Harjono 1996: 442). Thus, it appears that in social and civic life requires a leader (the ruler) to ensure the implementation of all things for the salvation and welfare of the people. According to Natsir, as in the teachings of Islam, there must be a mutual relationship between the leader and the people in the form of rights and obligations, so as not to cause anarchy and the use of arbitrary powers. The steps are the people must obey Ulil Amri as a leader. This obedience of the people is 
counterbalanced by the leader with his obligation to obey Allah and His Messenger, his loyalty to keep the trust of the people who have been given to him and the obligation of the principle of musyawarah (prioritize the deliberation) in carrying out his leadership (Natsir n.d: 11-14).

\section{Characters of the Head of State}

Regarding the qualities of a head of state, from various statements of Natsir, it appears that he is a believer of faith and noble, who have the character of subject to the Constitution, fair, honest and musyawarah (prioritize the deliberation).

\section{Muslim Who Believes Firmly}

In Natsir's belief for a country leader, there is something necessary other than science, experience, skills and so on, that is good morals, not dirty (akhlakul karimah) (Natsir 1987: 16). He states "Leaders must be noble and rooted in the hearts of the people" (Natsir 1987: 11).

Thus, in his view, the criteria and the size of a head of state are his religion, personality and character, morals and his ability to hold the powers granted to him. And not a nation and its descendants or merely intellectual (intelligence) alone (Natsir 1957: 448). Only to those leaders who believe and prove their faith with the deeds of worship that distinguishes Islam and kufr, according to him, who submit and obey the commandments of Allah and His Messenger, whose whole actions and movements are driven by the word of God and the sunna of His Prophet. Only to such leaders, the Muslims are lawfully obedient in the struggle to achieve their ideals. They are called Hezbollah, the army of God, promised victory because their movements are in the rule and recognized by the Almighty (Natsir 1957: 448). See al-Qur'an letter al-Maidah verse 56 and al-Nisa verse 144 . He states that "the destruction of a state, usually, is preceded by the wickedness of the leaders and leaders of the nation itself. Thus sunnatullah happens from time to time "(Natsir 1957: 35).

\section{Subject to the Constitution}

In terms of the constitution which is the identity and foundation of a country, according to Natsir, a head of state should submit and obeys to this constitution. "Head of State has no absolute power". This statement was put forward in response to a speech by President Soekarno in May 1957 which quoted and borrowed the words of the British leader "Constitution is made for men and not men for the constitution".

He states, that the acts of the Head of State will be a lot of influence on the actions of the people. If the head of state assumes that the constitution is a matter which if necessary should be abandoned, because it is made for human beings and not vice versa, while the constitution is the highest law in a country, then the people will take lightly to the constitution and let alone other rules. If that happens, then the joints of the state's living order will be shaky at all and only the law of the jungle will prevail. Every ruler is entitled to the obedience of the people and his subordinates. The right to the people's obedience is based on the obligation of the ruler to obey the Constitution and the existing rules (Natsir 1957: 5).

\section{Fair}

In the fair nature of the head of state, Natsir said that the stability of social life and state requires the establishment of justice. Anything that hurts the sense of community justice can lead to the destruction of the stability of society as a whole, because the sense of justice is the nature of man. To uphold justice, the law is sovereign over all elements of society, from the weakest to the highest leader. Everything is equal before the law (Natsir 1988: 8). According to 
Natsir, in upholding justice and the truth, the ruler can not be indiscriminate, depending on the pleasure or displeasure. Justice for the righteous is the means to uphold justice on objective grounds, not on the basis of the interests of any kind of family or group. He proposes the Qur'anic verse of An-Nisa verse 135 to reinforce his view (Natsir 1975: 55-56).

As mentioned above, the power that is in the hands of the head of state is a God's gift mandated to him to be executed in accordance with the norms set forth by the Allah-Just God. Power is not for the sake of justice, but to uphold law and justice, and grant the right to anyone who is entitled to it, even though the righteous is in a weak position. Allah reminds the rulers who indulge their own desires without thinking with the norms of justice and truth with their own destruction, as in the letter of Ibrahim verse 42.

\section{Honest}

In the case of honesty of a Head of State, Natsir argues that dishonesty in the signal as Head of State can add to the pointing of circumstances as well as incite sentiment, and is worried about causing hostility, because it gives rise to accusations of who is considered a state seller and betrayed him. According to Natsir, the function of the President is important as a symbol of unity of the concrete state and not vague. Thus, the speech and behavior of the head of state should be honest, real and objective, also not be sarcastic (Natsir 1957: 295). The principles of honesty, responsibility and respect for human rights are upheld. Leaders need not be shy about admitting their weaknesses and always willing to accept criticism and input from others (Natsir 1957: 295).

In answering the question "What should the leaders of Islam consider? He says that: First, be aware of their own real strengths and weaknesses, and of the forces facing and bringing the people to that consciousness. Second, organize struggle effort with systematic and certain program. He warns and affirms the proverbial truth that says "Wisdom that runs regularly can defeat the truth that is not well organized". The leader of Islam must realize that to lead is to hold to release, so that the cadre can walk on their own, as in the epistle of Maryam verses 4-6 which speaks of a leader's disquiet (Natsir 1957: 315-316). Only to such leaders the proverb is apply: "Broken grew lost". Do not forget, according to Natsir, the wisdom contained in the submission of the leadership of the Prophet s.a.w. to Abu Bakr when handing over pilgrims and worshipers. So did the war leader from Abu Bakr to Usamah ibn Zaid (Natsir 1957: 272-273).

\section{Deliberation}

Deliberation is the character that is important for the head of state in determining a decision he took. The matters discussed, according to Natsir, are not on laws that have provisions in religion, such as the implementation of mandatory worship, but which can be discussed are things that are outside the provisions of religious worship. This means that the revelation of Allah and the Sunna of the Prophet becomes the measure and criterion in filtering out what is to be used and what is removed (Natsir 1957: 449-450). In his judgment, like Islam, deliberation has value in regulating life, both in the life of society and in the life of the state. He is preserved, because it is a stipulation in the teachings of Islam that in order to deal with matters concerning the people, the ruler must obtain pleasure from the people he rules and he should deliberate everything that concerns the lives and interests of the masses. There are strict rules that read; "Wa syawirhum fi al-amri" (consult with them in affairs that concern themselves (Natsir n.d.: 131).

Concerning deliberations for consensus in determining a decision, he said, is based on democracy and full of tolerance, in the open tolerance of space and atmosphere as wide as possible for the difference of ideas and thoughts. Tolerance without dissent, in his view, is not really tolerance. What is needed is a difference of opinion in an atmosphere of tolerance so that 
from the clashes between ideas and thought-forward can produce truth (Natsir n.d.: 110). He expressed his view that the elements of democracy are, at a minimum, everyone realizes that he is an independent who has rights and duties for himself, his people and his country, and is good at respecting others; Clever consultation with others, respect for human dignity and have a spirit of tolerance (Natsir n.d.: 20-21). The well-known principles of democracy are: 1 . The ruling class must be approved by the largest group (majority), 2. Small groups of differing opinions from the majority are guaranteed the right to life in society (Natsir n.d.: 114).

\section{Appointment and Determination of Head of State}

As is known in the discussion above that a leader, in the view of Natsir, born from the bottom and grow in the field after interacting with various challenges. He was born as a leader because the community and his group considered him worthy to running the trust he received. From this statement, it shows the existence of natural selection from society to a leader. In other languages, the community establishes an electoral system (al-ikhtiyar) in determining a leader who will serve as their leader in individual and social life. Such a view is evident in Natsir's statement. He stated that elections are the path (goal) of determining a leader. The election system is one of the ways that God accepts in public and state life (Natsir 1957: 280-281).

As for the determination (ta'yin) a head of state, according to him, is not measured from the origin of the nation and his descendants (nasab). He states that "the most important thing for a person to become head of state is with respect to his attributes and the fulfillment of his rights and obligations and is accountable to the state and the people. It is not related and lies to the nation and its descendants "(Natsir 1957: 447). The value of the nation and nationhood is not measured by pride. But the value of the nation and nationhood is measured by the many devotions to the nation, the homeland and God (Natsir 1955: 9).

In his view, a leader of the state, people and society should win the trust of their people, and of course accompanied by the reputation, charity and service leaders who are known by the people. Instead society or people do not choose leaders who have not shown their charity and services. However, placing a person as a leader means giving up some of his rights to the person chosen as the leader (Natsir 1993: 14). In addition, he also expressed that the criteria or measures set for a person to be sworn in as head of state are his religion, personality and character, as well as his character and his ability to hold the powers granted to him. So it is not the nation and the descendants or the intellect alone (Natsir 1957: 448). It is known that the size of a person, not in his aspirations and position alone, especially in his personal character, his character, his struggle and his charitable efforts in fulfilling the trust and trust of the people (Natsir 1987: 43).

From the above statement, it turns out that for Natsir nasab problem or the descendants of a person does not become the most important thing in leadership. What is important for him is his religion, personality, morals, skills, intellectual and devotion to the nation, homeland and his God. His views at the same time reject the notion that the nation and the descendants of a leader to be decisive in his leadership, as understood in the classical period of Islam that saw that the leaders were from descendants of Quraish.

In the case of the swearing (bay'ah), according to Natsir it is necessary to be carried out by the leader in the mosque, as the Prophet also uses the mosque to carry the bay'ah, the sacred promise, and the mubaya'ah between each other in the struggle of Allah's word (Natsir n.d: 10).

Bayah's understanding, in Natsir's view, is a sacred covenant between the ummah and its leader in defending their self to the last drop of blood. It is apparent in his view that in the lifetime of the Prophet, before the Hudaibiyah treaty took place, there was a bay'ah when the Muslims were being threatened by the Quraysh who were about to invade unarmed Muslims in order to perform Umrah. The meaning of bay'ah in the event is a very sacred (serious) 
agreement between the Prophet and the ummah that is to defend them to the last drop of blood (Natsir 1987: 35-36).

From the above phrase, it appears that two kinds of bay'ah are performed, bay'ah spoken by the leader (aqad) as oath and promise in the lead, and bay'ah by the ummah/people through its participation in the election against the leader. This is based on the origin of the meaning of the word bay'ah which means selling or giving some of the voting rights to the leader, as Natsir understands that placing a person as a leader by the people means giving up some of his rights to the leader mentioned above.

\section{Islam and Pancasila}

In examining and understanding the issue of faith in the view of Natsir and related to the context of Indonesianness, the discussion can not be separated from the problems of Islam and Pancasila or the unity of religion and state. As it is known that aqeedah or religious belief, he argues, is "a source of motivation, a source of inspiration, a source of strength to withstand pain, a starting point for doing, a grip of life to be brought to death" (Natsir 1984: 13). Islam, for him, is an ideology devoted to God's revelation. Islam is not merely a religion in the sense of a human relationship with God alone. Islam contains two elements, namely the element of human relations with God and the element of human relationships with fellow beings. The elements of worship and mu'amalah (Natsir n.d: 129). Revelation as a source of trust and faith in God, free from temporal influences, such as agrarian, nomadic or industrialism, radiates like springs that emit life's eternal antidote and liberate people from being lost and continue to grope for God (Natsir n.d. 122).

The Pancasila, he argues, is not believed to be a religion, because, it is not originated from any of the God's revelations. It is the excavation of people's lives. He is not an acknowledgment and a witness of God's sovereignty with all its consequences to the acknowledgment of a positive God's law. It is simply a 'sense of God' without revelation, without consequence; the sense of the existence of God, as a relative human creation, is changing. He can not say anything to the souls of the religious people. Pancasila can not reflect what life is raging in the souls of Indonesian society (Natsir n.d.: 126-127). Pancasila is an abstraction, a "pure concept" which in reality can not stand alone (Natsir n.d.: 128).

In the meantime, Natsir declares and warns the Indonesian Muslims that the Pancasila which is the basis of the state is nothing more than a formulation that is still a shadow, as long as it is not filled with monotheism. Pancasila will not be fertile its life in the midst of the people of Indonesia if it is not filled and distributed according to Islamic teachings. And otherwise Pancasila will die, meaning nothing, if it is filled with ideals of materialism. And Islam is the mother of all Principe in Pancasila (Natsir 1955: 9). If Pancasila is filled with monotheism, then it will not be contrary to Islam. However, if the Pancasila is not filled with monotheism, it is contrary to Islam (Natsir 1955: 9).

In commenting on and responding to Pancasila that is laid as the basis of the state in the life of the nation and state, Natsir said that Pancasila is a foundation that is not at all contrary to the Qur'an. Even Pancasila is the values that will flourish on the foundation of Islam. It does not contradict the everlasting God's revelation. However, Islam provides with great standards based on the Qur'an and al-Sunnah. None of the precepts listed in Pancasila are contradictory and intersect with Islam. Therefore, Natsir urged that Pancasila should not be used as a tool to challenge the precepts and teachings of Islam. It is a way of life, a life-giving way that gives life and life to the state and all the inhabitants of the country with no discrimination (Natsir 1955: 6). Pancasila is a "political statement, not a theological statement". And therefore, the Pancasila Guideline is supposed not to interfere with matters that are not directly within the authority of the State (Natsir 1982: 24).

From the above statement, it appears that Natsir puts Pancasila on the correct portion and Islam in the correct portion as well. He opposed the confusion of Pancasila with religion and 
the confusion of religion with Pancasila. He declared: "Do not make Pancasila a Religion and Conversely Do not make Religion a Pancasila" (Natsir 1982: 24). Relating to the relationship of religion and state, he has the view of unity (tauhid) between the two. This means that the issue of religion can not be separated from the state and vice versa the state is closely related to religion. However, he does not intend to make Islam a formally established ideology in the form of a formulated Islamic state. Islam, for him, refers more to the behavior, morals (ethics) of human beings as individuals of a society and a state based on Islamic values. The state is merely a tool to socialize the values of justice and the liberation of mankind from suffering and misery (Mahendra 1994: 4).

The goal of Islam is for religion to live in individual life so that it seeps into the life of society, state, government and legislation. He gave an example of the development of statehood and government under the leadership of Prophet Muhammad SAW and the Caliph of Rashidun on the affairs of the state and the development of the schools of thought within Islam, shows that the considerable extent of the concessions that Islam provides for the evolution of society within the bounds of the principle and teachings of the Qur'an (Natsir 1957: 69).

Furthermore, in the conception of the country, Natsir agreed with Mohammad Iqbal. He argued that the state should be based on the teachings and principles of Islam. This view arises because of his belief that in Islam between politics and religion should not be separated. State and religion are unity that can not be separated. In this regard, he also argues that the concept of separation of religion from the state comes from Western thought. In Western thought, political theory or way of thinking like this is manifested by the separation of the emperor's square and the pope's field. The result of this separation, seen in several forms, among others: 1) the separation of the spiritual values of the material values in life with absolute; And 2) the rationalism already embedded in the soul of the Indonesian beings, becomes a factor which controls the whole, not inhibited any more by the spiritual energy worthy of compensating for the forces of rationalism. So the mastery of knowledge merely in turn embodies racism, narrow chauvinism ('asabiyah jinsiyah), the accumulation of wealth in the hands of some, the creation of special classes and groups, the development of antagonism or class animosity, Mastery of one group over the other, all of which will give rise to hatred, vengeful resentment and war for the battle (Natsir 1957: 104-105).

However, the question that arises is Whether Islam or Pancasila desired by Natsir as the basis of the state? He actually accepted Pancasila as the foundation of the state of Indonesia. It is apparent that when he became prime minister of a Pancasila state, he did not question the Pancasila. But then came the image that he was fighting for an Islamic state, especially in the 1959 Constituent Assembly (Natsir 1993: 14).

Natsir's submission to Islam as the basis of the State in the Constituent Assembly took place with several considerations. Namely, in addition to Muslims as the majority of the population in Indonesia, Islamic teachings that have statehood and living society have the perfect traits for the life of the state and society and can guarantee the diversity of life for mutual price-valuing among the various classes within the state. The proverbial saying "Even if great will not strike, even if high will protect instead" (Natsir N.d: 116). In addition, the Constituent Assembly is indeed established to determine the basis of the state. Because there is a chance and struggling for a constitutional Islamic state, so Natsir and his friends like Wahid Hasyim, Abikusno Tjokrosuyoso and Kahar Muzakkar, fight for Islam as the basis of the state. Not only Natsir from Masyumi, but also from three other Islamic parties: NU, Perti, and PSII. And it just so happens that he is the most articulates, the most spokesperson, explaining more and his ideology of the Islamic element is embranced. But when seen, when in Pakistan in the post as prime minister, Natsir said that Pancasila is already Islam. And this means he accepts Pancasila. $\mathrm{He}$ also said that Pakistan established as an Islamic country and Indonesia that became Pancasila state is no different, because the first precepts of Pancasila are the One Supreme 
Godhead, which means monotheism. So actually, Natsir sincerely accepted Pancasila (Natsir 1993: 14).

Thus, the religious belief in a country, in its view, becomes very important and has implications for the people and the country. Natsir argues that religion as the basis of the state has the advantage of secularism. Namely: First, Religion gives its adherents more possibilities to seek knowledge and truth. All secular philosophies recognize three basic thinking, namely Empiricism (tajribah mazhab), rationalism (aqli mazhab) and intuitionism (ahhami mazhab). The basis of revelation or openbaring is not admitted. Religion is more than that. Religion acknowledges everything and provides strict provisions in which the respective areas apply. Secondly, the idea of religion encompasses all parts of life (Natsir 1993: 125). He states: "It is very dangerous for a business to produce the foundation of the State, if the thoughts that arise in its discussion are not clear, vague and disguised" (Natsir 1993: 109).

In this case, Natsir gives some conclusions about the unity of religion and state: First, Islam is different from other religions, in its rules has some sections relating to the laws of state and uqubah (penal), and mu'amalah, which all of them are parts that can not be separated from Islam itself. Second, people who do not want If the state runs all the rules of Islam with the reason the state should be separated and stand on all religions or for democratic reasons, in essence not separating the religion from the state but cast some of the laws of Islam. Thirdly, Islam is democratic, but not all of its laws should be deliberated and approved by Parliament. In an Islamic state the thing that needs to be deliberating and approved is a mundane affair which has not and has no legal provision in religion (Natsir 1957: 490-492).

\section{Criticism of Natsir's Thought on Islam and Pancasila}

Islam and Pancasila in Indonesia are still an unfinished problem. The attitude of Indonesian Muslims is divided into three groups. The integralistic group (Islam as the formal state base), the nationalist group (rejecting the view which declares Islam as the basis of the state formally), and the modernists assume there is no contradiction between Islam and Pancasila so that Pancasila can be accepted as the basis of the majority Muslim nation Indonesia state. In examining and understanding the aqeedah or the nationality and the basis of the state From $\mathrm{M}$. Natsir point of view, related to the context of Indonesianness, the discussion can not be separated from the problems of Islam and Pancasila or the unity of religion and state. Islam, for him, is an ideology sourced to divine revelation. Islam is not merely a religion in the sense of a human relationship with God alone. Islam contains two elements, namely the element of human relations with God and the element of human relationships with fellow beings. The element of worship and muamalah (Natsir n.d.: 129).

Responding to M. Natsir's statement above regarding Islam and Pancasila, Hidayat Nataatmaja (2007: 133-136) asserted that Islam and Pancasila are two interrelated things, with Pancasila Muslims can establish a legally universal Islamic civilization in Indonesia. Islam is a system of life that according to its followers to actively embody in the life of Muslims in the real world. Included in the life of nation and state. For that needed political power to make it happen. But political power is not meant to manifest the formal side of formal Islamic symbols like the Islamic state. But what is strived to apply is the side of Islamic values or its substance.

In line with the above opinion, Yudi Latif (2015: 99). In his book entitled "Negara Paripurna Historisitas, Rasionalis, dan Aktualitas" Stating that Islam is basically a system of life that according to its followers to actively embody in the life of Muslims in the real world. Included in the life of nation and state. Islam is a source of inspiration and motivation, an ethical and moral basis, not as a social and political system as a whole, but must be captured by spirit and spirit. Therefore, the basis of Islamic political thought is the contextualization of the doctrinal text in order to actualize the teachings of Islam. In the form of Pancasila Islamic teachings in the empirical world seen from the establishment of justice, freedom, and welfare of 
the people. This shows that when the majority of people's characters are strong, positive, tough, high civilizations can be built well and succeed, otherwise if the majority of the people's characters have negative and weak characters resulting in a weakened civilization, because the civilization is built on a very foundation weak.

The Pancasila, he argues, is not believed to be a religion, for, it is not originated from any of the divine revelations. He is, as it turns out, the excavation of the life of the people. He is not an acknowledgment and a witness of God's sovereignty with all its consequences to the acknowledgment of a positive divine law. It is simply a 'sense of God' without revelation, without consequence; the sense of the existence of God, as a relative human creation, is changing. He can not say anything about the souls of the religious people. It can not reflect what life is raging in the souls of Indonesian society (Natsir n.d.: 126-127). Pancasila is an abstraction, a "pure concept" which in reality can not stand alone (Natsir n.d.: 128). Munawir Sjadzali (1997) is a Muslim modernist who asserts that Islam and Pancasila are not contradictory, but they are two things that related to each other, Islam is the source of norms and moral values, while Pancasila is a container to run it Islamic values in everyday life in Indonesia. Pancasila is the substance of Islamic teachings itself, with Pancasila Muslims can build a legal Islamic civilization legally in Indonesia. Pancasila is a state ideology that is based on the substance of Islamic teachings that have been the soul of Indonesian Muslims for a long time. Therefore, the struggle to create an Islamic state and civilization can be done through Pancasila which is a common benchmark of how to think, how to judge, and how to behave throughout the Indonesian nation. For that we need concrete thoughts and examples such as those capable of reading phenomena and translating in the life of the nation and state. With the honesty of science and Islam as well as politics that can bridge the ummah as a whole without any feel alienated, moreover feel lost his identity.

From some of the above statement, regarding Islam and Pancasila, it is understood that in building the Indonesian state the strategy to be done is to actualize the source of Islamic teachings in Indonesian values, as the character of the Indonesian nation conceptually using the moral pillars (Pancasila). Individual and communal characters are built through two interrelated aspects of autonomy and heteronomic aspects. Autonomy is an effort in the educational process that is implemented through teaching, habituation, modeling, motivation, and law enforcement. Meanwhile, the hetero- nomic aspect is an effort done by the environment (outside of education) namely the existence of social economic justice, lawless lawlessness, exemplary leadership, and regularity of social norms. Through Pancasila which is subtantif the values of Islamic teachings, the Indonesian nation to build new sciences. Above the new sciences is built a new social system. With this new social system, Muslims organize new society. With a new society that is organized in Islam that Muslims build an Islamic civilization without a formal Islamic name. With the Islamic heritage buildings that Muslims can compete and surpass other civilizations of the world, intelligently and dignified.

To conclude, Natsir's political thinking which has a high social concern needs to be emulated by scholars and intellectuals. Natsir contributes actively constructive thoughts in the improvement of living standards, eliminates or reduces the quantity and quality of oppression and corruption, moral depravity and hypocrisy.

In addition, Natsir also emphasized the importance of heads of state that are having morals, democratic, and constitutional and get popular support. In summary Natsir's political thought proposes the conception of a moral state and a clean government. Keywords can be drawn from the concept of the state that it is trying to develop by Natsir is that the ideal state concept is the existence of a system of values of justice, responsibility, and morality of all elements of the state, both from the elite currents to the downstream, which together control the color of state policy in order to create order, social harmony, and the growth of civilization dynamically. 


\section{References}

Balandier, Gergoes. 1986. Antropologi Politik, Terj. Y. Budi Sanstoso. Yogyakarta: Rajawali Pers. Hakiem, Lukman. 1993. Pemimpin Pulang: Rekaman Peristiwa Wafatnya M. Natsir. Jakarta: Yayasan Piranti Ilmu.

Haryono, Anwar. 1996. Pemikiran dan Perjuangan Mohammad Natsir. Jakarta: Pustaka Firdaus. Junus, Mahmud. 1985. Sejarah Pendidikan Islam di Indonesia. Jakarta: Hidakarya Agung.

Latif, Yudi. 2015. Negara Paripurna Historisitas, Rasionalis dan Aktualitas. Jakarta: PT. Gramedia.

Mahendra, Yusril Ihza. 1994. Modernisme Islam dan Demokrasi: Pandangan Politik Mohammad Natsir. Islamika. No.3. January-March.

Nataatmaja, Hidayat. 2007. Indonesia Bergerak, Agenda Menuju Kebangkitan. Yogyakarta: Lanskap.

Natsir, Mohammad, 1955. Moh. Natsir di Ibu Kota Sumatra Tengah. Hikmah. 33. 13 August.

Natsir, Mohammad. 1957. Capita Selecta 2. Pustaka Pendis: Jakarta.

Natsir, Mohammad. 1967. Ilmu, Kekuasaan dan Harta Adalah Amanat Allah. n.p. Bulan Bintang.

Natsir, Mohammad. 1975. Iman Sumber Kekuatan Lahir dan Batin. Jakarta: Fajar Shadiq.

Natsir, Mohammad. 1982. Dunia Islam dari Masa ke Masa. Jakarta: Panji Masyarakat.

Natsir, Mohammad. 1984. Asas Keyakinan Agama Kami. Jakarta: Dewan Dakwah Islamiyah Indonesia.

Natsir, Mohammad. 1987. Pendidikan Pengorbanan Kepemimpinan Primordialisme dan Nostalgia. Jakarta: Media Dakwah.

Natsir, Mohammad. 1988. Demokrasi di Bwah Hukum. Jakarta: Media Dakwah.

Natsir, Mohammad. 1989. Percakapan Antar Generasi: Pesan Perjuangan Seorang Bapak. Jakarta: Media Dakwah.

Natsir, Mohammad. 1993. Kiat menjadi pemimpin. Suara Masjid. No. 223/April 1993.

Natsir, Mohammad. n.d. Kepemimpinan dalam Suara Masjid. No. 15/Tahun IV, Jakarta.

Noer, Deliar. 1990. Gerakan Moderen Islam di Indonesia. 1900-1942. Jakarta: LP3ES.

Puar, Yusuf A. 1978. Mohammad Natsir 70 Tahun: Kenang-Kenangan Kehidupan Perjuangan. Jakarta: Pustaka Antara.

Salam, Solichin. 1990. Wajah-Wajah Nasional. Jakarta: Pusat Studi dan Penelitian Islam.

Sjadzali, Munawir. 1997. Islam Realitas Baru dan Orientasi Masa Depan Bangsa. Jakarta: UI.

Sukarja, Ahmad. 1995. Piagam Madinah Dan Undang-Undang Dasar 1945. Jakarta: UI Press.

Syamsuddin, M. Din. 2001. Islam dan Politik Era Orde Baru. Jakarta: Logos Wacana Ilmu. 